\title{
Effect of Colonization of Pear Stigmas by Pseudomonas syringae pv. syringae on Fruit Set
}

\author{
E. Lucienne Mansvelt ${ }^{1}$ and F.J. Calitz ${ }^{2}$ \\ INFRUITEC(Stellenbosch Institute for Fruit Technology), Private Bag X5013, \\ Stellenbosch 7599, South Africa
}

Additional index words. blossom blast, Pyrus communis

\begin{abstract}
Packham's Triumph' (Pyrus communis L.) pear blossoms were inoculated with Pseudomonas syringae pv. syringae van Hall upon emasculation and then hand-pollinated at different times to assess the effects of bacterial colonization on fruit set. The pathogen significantly reduced fruit set by $\mathbf{2 4 \%}$. No lesions developed on pear flowers at any stage of the trials.
\end{abstract}

Fruit set in the pear-producing areas of the southwestern Cape Province of South Africa is often poor, and in some years $>90 \%$ of fruitlets abscise. Bacterial blossom blast caused by Pseudomonas syringae pv. syringae ( $P$. s. pv. syringae) (Mansvelt and Hattingh, 1986) contributes to limiting pear production. Dormant buds harbor the pathogen and, at bud swell, open and supply primary inoculum. Flowers are infected in early spring during wet, humid conditions. A previous study has shown that the stigmas are important sites of colonization by the bacterium (Mansvelt and Hattingh, 1987). Occupation of pearl millet [Pennisetum americanum (L.) Leeke] stigmas by the ergot fungus restricts pollination (Willingale et al., 1986). This study was undertaken to determine if bacterial colonization of the pear stigma by P.s. pv. syringae influences pollination and fruit yield.

\section{Materials and Methods}

Full-bearing 'Packham's Triumph' pear trees growing in a commercial orchard at Somerset-West in the southwestern Cape Province were evaluated during Oct. (Spring) 198990 and 1990-91 for their ability to set fruit following bacterial inoculation and hand crosspollination. For each season, a single separate row with 16 (1989-90) or 18 (1990-91) trees was selected. Twenty-five floral clusters at white bud were chosen at random on a tree. One tree represented an experimental unit, and trees were treated with either a suspension of $P$. s. pv. syringae or sterile distilled water. Subsequently, hand-pollinations were performed eight (1989-90) or nine times (199091).

\footnotetext{
Received for publication 12 Apr. 1993, Accepted for publication 9 Aug. 1993. We thank Martin Hattingh and Isabel Roos for carefully reading the manuscript. The cost of publishing this paper was defrayed in past by the payment of page charges. Under postal regulations, this paper therefore must be hereby marked advertisement solely to indicate this fact.

'Research Plant Pathologist.

'Biometrician
}

Pollen was harvested from 'Clapp's Favourite' flowers at anthesis and stored at $-20 \mathrm{C}$ until needed. Inoculum of $P$. s. pv. syringae strain L795 was prepared as described previously (Mansvelt and Hattingh, 1986). Inoculum concentration was adjusted to $2 \times 108$ colonyforming units $(\mathrm{cfu}) / \mathrm{ml}$.

Stigmas of three flowers per cluster were inoculated immediately after emasculation by placing a drop of inoculum suspension on the Nontreated flowers on the cluster were removed. Inoculated flowers were covered immediately with polyethylene bags humidified with sterile distilled water. Bags were secured with clothes-pegs. Clusters remained bagged until stigmas were hand-pollinated.

Stigmatic surfaces were hand-pollinated with a glass rod that had been dipped into the pollen at $0,3,6,18,24,30,48$, and $72 \mathrm{~h}$ after inoculation. A 40-h pollination treatment was included for the second season.

To monitor bacterial populations at each stigmatic surfaces with a pasteur pipette. pollination time, one flower per cluster was removed and individually placed in empty, sterile test tubes. Test tubes were stored in a cooler bag in the field and kept at $4 \mathrm{C}$ in the laboratory. Within $24 \mathrm{~h}$, each flower was suspended in $10 \mathrm{ml}$ of sterile water, vortexed, and serial dilutions of wash fluids were made in duplicate onto medium B (King et al., 1954). Plates were incubated for 2 days at $27 \mathrm{C}$ and the number of colonies was counted. Representative isolates were characterized as described previously to confirm identity of $P . s$. pv. syringae (Mansvelt and Hattingh, 1986). The two remaining flowers per cluster were left on the tree to allow fruit set to occur. After 8 weeks, the number of fruits per flower that had set was recorded.

\section{Results and Discussion}

Regression analyses were performed on the data. No significant differences ( $F^{\prime}>0.05$ ) were found between trends of the same treatment for the-two seasons; thus, the results were combined.

The pathogen increased rapidly in the first $24 \mathrm{~h}$, to reach a level of $1.48 \times 105 \mathrm{cfu} / \mathrm{blossom}$ on inoculated stigmas, after which it stabilized (Fig. 1). Control flowers showed no significant trend $(P=0.9)$ in the viability counts.

Throughout the investigation, fruit set of uninoculated flowers was consistently higher than those inoculated with $P$. s. pv. syringae (Fig. 2). The time of pollination did not influence the numbers of fruit formed-a constant fruit set of $18 \%$ was recorded for those inoculated. On uninoculated flowers, the initial percentage set was $18 \%$, which increased to $42 \%$ $24 \mathrm{~h}$ after inoculation and then declined to $24 \%$ after $65 \mathrm{~h}$

The maximum, minimum, and average temperatures for each season for the 4 days after inoculation were within the normal range for the localities where pear trees are grown (Table

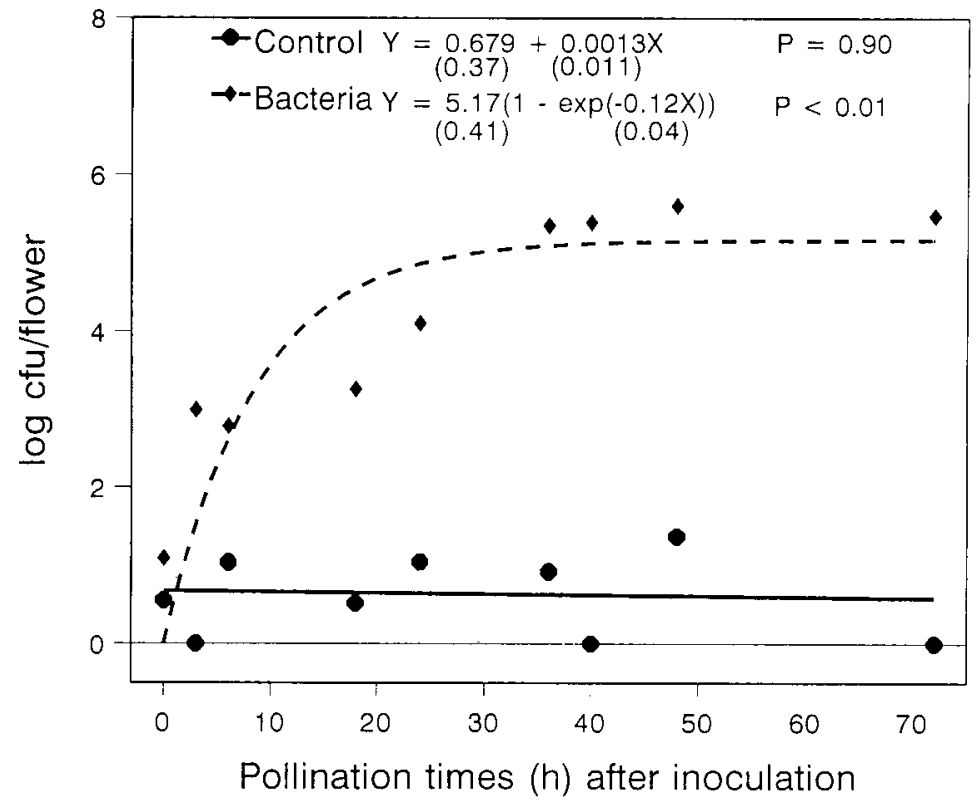

Fig. 1. Viable population levels of Pseudomonas syringae pv. syringae on 'Packham's Triumph' pear stigmas at selected times after inoculation. Control flowers were treated with sterile distilled water. 


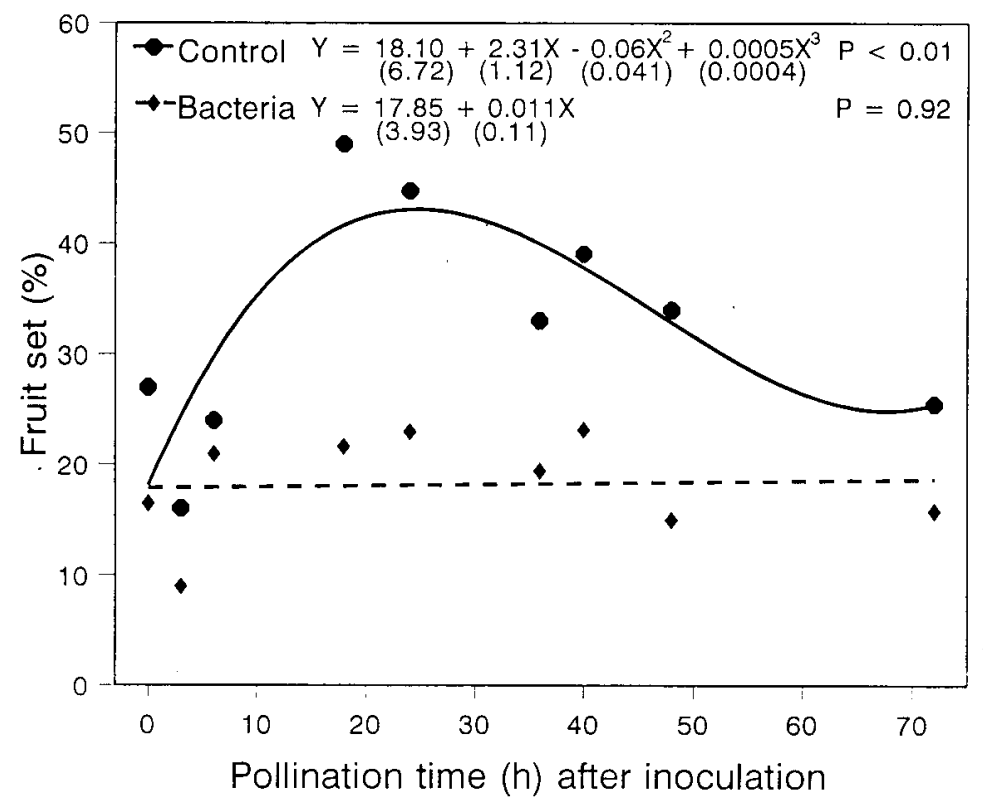

Fig. 2. Percentage fruit set of 'Packham's Triumph' pears after hand-pollination at selected intervals. Flowers were emasculated just before anthesis and then inoculated with Pseudomonas syringae pv. syringae simultaneously. Controls were treated with sterile distilled water. Fruit set per 50 flowers on 25 clusters was recorded 8 weeks after pollination.

1). No rain fell during the study period, and subzero temperatures resulting in characteristic blast symptoms were absent.

Colonization of pear stigmas by P. s. pv. syringae restrained pollination and, therefore, reduced fruit set. Almost all the flowers inoculated with $P$. s. pv. syringae were colonized (data not shown). In both seasons, $P$. s. pv. syringae population levels increased after inoculation. No symptoms developed, although floral structures were exposed upon emasculation. The presence of bacteria on stigmas reduced fruit set by $24 \%$, absolute, and $57 \%$, relative, to the control.

The effective pollination period of flowers can be affected by the length of time that the stigma remains receptive, the suitability of style tissue, or the duration of ovule viability. Whether one or more of these factors limit fruit set depends on genetic, environmental, or cultural factors (Williams et al., 1984). Stigma receptivity and ovule viability are rather short in fruit trees (Egea et al., 1991). For example, in Oregon, the effective pollination period of
'Cornice' is around 5 days (Crisosto et al., 1992). In this study, uninoculated flowers had an adequate fruit set, i.e., $>20 \%$, in the 4 days of hand-pollinations.

Scanning electron microscopy (SEM) indicated that the exudates produced by stigma on sweet cherry (Prunus avium L.) create a favorable environment for fungal development (Tonutti et al., 1991). The high humidity at stigmatic surfaces for pollen hydration probably favors bacterial multiplication as well. In lae of stigma and pollen of 'Packham's Triumph' pears were highly colonized by P.s. pv. syringae (Mansvelt and Hattingh, 1987).

No lesions developed on the gynoecia, even though population levels higher than $1.48 \times 10^{5} \mathrm{cfu} /$ flower were monitored. Whitesides and Spotts (1991) reported that blossom blast was consistently induced 2 to 3 days after inoculation on flowers in full bloom when appropriate moisture and temperature (21C) were available. Symptoms on pear stigmas and styles attributable to $P$. s. pv. syringae a previous study, SEM revealed that the papil-
Table 1. Temperature data for Oct. 1989-90 and Oct. 1990-91 (Southern Hemisphere) from 'Packham's Triumph' pear orchards, Cape Province, South Africa, during bloom, when inoculations with Pseudomonas syringae pv, syringae and emasculations were performed. No rain fell during these investigation periods.

\begin{tabular}{lcccc}
\hline \hline & $\begin{array}{c}\text { Days after } \\
\text { inoculation }\end{array}$ & Maximum & Minimum & Avg \\
\hline Season & 1 & 16.6 & 10.0 & 13.3 \\
\hline $1989-90$ & 2 & 22.0 & 9.4 & 15.7 \\
& 3 & 25.0 & 11.5 & 18.3 \\
& 4 & 29.8 & 15,0 & 22.4 \\
$1990-91$ & 1 & 16.0 & 12.0 & 14,0 \\
& 2 & 18.5 & 10.0 & 14.3 \\
& 3 & 19.5 & 11.0 & 15.3 \\
& 4 & 23.0 & 12.5 & 17.8 \\
\hline
\end{tabular}

have been described (Mansvelt and Hattingh, 1986). However, the nectariferous tissue in the floral cups appears to be the major route for blossom infections (Mansvelt and Hattingh, 1987). In this study, the physiological status of the stigma before anthesis probably inhibited infection, which is why a resident population was established.

Under optimal conditions, a fruit set of 42\% was obtained. Pseudomonas s. pv. syringae can reduce this figure to $18 \%$, which translates to a crop loss $>50 \%$.

The mechanisms whereby bacteria affect fruit set is uncertain. SEM showed that $P$. $s$. pv. syringae is capable of colonizing pollen and causing disintegration of the grain (Mansvelt and Hattingh, 1987). The P. s. pv. syringae population possibly competes with pollen for stigma exudates, while pollen could be ruptured by the pathogen. Whether colonization of stigma lowers pollen adherence is unknown.

To our knowledge, this is the first report of reduction in fruit set by a bacterial pathogen. These results emphasize the importance of good orchard management during the growing season to keep inoculum levels of $P$. s. pv. syringae low.

\section{Literature Cited}

Crisosto, C. H., P.B. Lombard, D.G. Richardson, and R. Tetley. 1992. Putrescine extends effective pollination period in 'Cornice' pear (Pyrus communis L.) irrespective of post-anthesis ethylene levels, Scientia Hort. 49:211-221.

Egea, J., L. Burgos, J.E. Garcia, and L. Egea. 1991. Stigma receptivity and style performance in several apricot cultivars. J. Hort. Sci. 66: 19-25.

King, E. O., M.K. Ward, and D.E. Raney. 1954. Two simple media for the demonstration of pyocyanin and fluorescein. J. Lab. Clin, Med. 44:301 -307,

Kliewer, W.M. 1977. Effect of high temperatures during the bloom-set period on fruit-set, ovule fertility and berry growth of several grape cultivars. Amer. J. Enol. Viticult. 28:2 15-222.

Mansvelt, E.L. and M.J. Hattingh. 1986. Pear blossom blast in South Africa caused by Pseudomonas syringae pv. syringae. Plant Pathol. 35:337343.

Mansvelt, E.L. and M.J. Hattingh. 1987. Scanning electron microscopy of pear blossom invasion by Pseudomonas syringae pv. syringae. Can. J. Bet. 65:2523-2529.

Tonutti, P., A. Ramina, F. Cossio, and G. Bargioni. 1991. Effective pollination period and ovule longevity in Prunus avium L. Adv. Hort. Sci. 5:157-162,

Whitesides, S.K. and R.A. Spotts. 1991. Induction of pear blossom blast caused by Pseudomonas syringae pv. syringae. Plant Pathol. 40:118127.

Williams, R.R. 1965. Factors affecting pollination in fruit trees. n. 193-207. In: L.C. Luckwill and C.V. Cuttings (eds.). Physiology of tree crops. Academic, New York.

Williams, R. R., P. Brain, R.M. Church, and V.A. Flook. 1984. Flower receptivity, pollen transfer and fruit set variations during a single flowering period of Cox's Orange Pippin apple. J. Hort. Sci. 59:337-347.

Willingale, J., P.G. Mantle, and R.P. Thakur. 1986. Postpollination stigmatic constriction, the basis for ergot resistance in selected lines of pearl millet. Phytopathology 76:536-539, 